\title{
Climate Change and Regulation in Interna- TiOnAl ANd Regional LeVel, Especially the Built ENVIRONMENT
}

\author{
Zsuzsanna Putnoki \\ Institute of Civil Engineering, Szent István University, Budapest, Hungary \\ putnoki.zsuzsanna@ybl.szie.hu
}

\begin{abstract}
The article starts with a brief insight into the history of climate change, with a scope on the international and legal aspects of ever-changing regulations. The regional level is in the article is The European Union, as the only regional economic integration organization under the Kyoto Protocol. It deals with the United Nation's international agreements like UNFCCC its Kyoto's Protocol and the Post-Kyoto era. It also analyses the EU's system in the climate change law with correspondence the international rules. Comparison between international and regional legislation in the climate change is used as a tool of analysis. Finally an insight is given into a special field in the climate change, the build environment, reflecting on the related United Nation's recommendation and the EU's regulation.
\end{abstract}

Keywords: Climate change regulation, UNFCC, Kyoto Protocol, Post-Kyoto era, European Union, built environment in climate change.

\section{SHORT HISTORY OF CLIMATE CHANGE SCIENCE, POLICY AND LAW}

As Joseph Fourier told in 1824: „The earth receives the rays of the sun, which penetrate its mass, and are converted into non-luminous heat; it likewise possessed an internal heat with which it was created, and which is continually dissipated at the surface; and lastly, the earth receives rays of light and heat from innumerable stars, in the midst of which is placed the solar system. These are the three general causes which determine the temperature of the earth."

Jean Baptiste Joseph Fourier is best known for his Fourier series. He was a mathematics teacher and he was probably the first person, in 1827, to allude to the greenhouse effect when he compared the influence of the atmosphere to the heating of a closed space beneath a pane of glass. Fourier may also be credited with the suggestion that human activities could influence the climate. ${ }^{1}$ The final footnote of his memoir was a reference to his ,Theorie analytique de la chaleur", which appeared in 1822 and was translated in English in 1878. In this book, Fourier introduces the elements of a comprehensive mathematical theory of heat: the differential equations describing the movement of heat in solids and fluids, the variations introduced by external periodic heat sources, and the transmission of heat by diaphanous substances. ${ }^{2}$

Svante August Arrhenius is best known as an electrochemist (he received the Nobel Prize for Chemistry in 1903.), who was born near Uppsala, Sweden, on February 19, 1859.

1 M. D. H. Jones and A. Henderson-Sellers: History of the Greenhouse Effect, Prog. Phys. Geog. 14, no. 1; 1990. p. 5.

2 James Rodger Fleming: Historical Perspectives on Climate Change; Oxford University Press, 1998. New York. p. 62. 
He published numerous articles and several books on earth science and cosmology. Arrhenius developed a theory to explain the ice ages, and in 1896, he was the first scientist to attempt to calculate how changes in the levels of carbon dioxide in the atmosphere could alter the surface temperature through the greenhouse effect. The following equivalent formulation of Arrhenius' greenhouse law is still used today ${ }^{3}$.

The world's first climate conference was in 1979. and it was organized by World Meteorological Organization (WMO). It was followed by the Intergovernmental Panel on Climate Change (IPCC). 3-14th June 1992., the United Nations (UN) organized the first international „Earth Summit”, or officially United Nations Conference on Environment and Development (UNCED) in Rio de Janeiro with 172 participant governments. It has another name, the Rio Conference $e^{4}$ The "Rio Convention", officially the United Nations Framework Convention on Climate Change (UNFCCC) $)^{5}$, is one of three adopted at the "Rio Earth Summit" in 1992.

\section{Intergovernmental Panel on Climate Change}

IPPC was established by WMO and the United Nations Environment Programme ${ }^{6}$ (UNEP). Currently are 195 countries $^{7}$ are members (because it has an intergovernmental body. The IPCC is a scientific body under the support of the United Nations. The reason for the creation of IPCC was to find out whether there is anthropogenic contribution to the climate change, and if so, to what extent. The IPCC collects datas, creates databases, makes analysis and provides scientific information about climate change to everyone. In 1990 the IPCC published its First Assessment Report (Working Group I-Climate Change: The IPCC Scientific Assessment; Working Group II-Climate Change: The IPCC Impacts Assessment; Working Group IIIClimate Change: The IPCC Response Strategies). The UN General Assembly noted the report findings and decided to initiate negotiations for a framework convention on climate change. The Second Assessment Report in 1995 provided important material drawn on by negotiators in the run-up to adoption of the Kyoto Protocol in 1997. The Third Assessment Report came out in 2001 and the Fourth in 2007. The Fourth Assessment Report paid greater attention to the integration of climate change with sustainable development policies and relationships between mitigation and adaptation. ${ }^{8}$ Nowadays, the IPCC presented the Fifth Assessment Report ${ }^{9}$ (AR5 was released in four parts between September 2013 and November 2014.). The IPCC won the Nobel Peace Prize in 2007 (with Albert Arnold Gore Jr), the prize motivation was: ,for their efforts to build up and disseminate greater knowledge about man-made climate change, and to lay the foundations for the measures that are needed to counteract such change" 10 .

3 Example: The Intergovernmental Panel on Climate Change (IPCC): Climate Change 2013. The Physical Science Basis s. Contribution of Working Group I to the Fifth Assessment Report of the Intergovernmental Panel on Climate Change [Stocker, T.F., D. Qin, G.-K. Plattner, M. Tignor, S.K. Allen, J. Boschung, A. Nauels, Y. Xia, V. Bex and P.M. Midgley (eds.)]. Cambridge University Press, Cambridge, United Kingdom and New York, NY, USA, 1535 pp.

4 The series of Rio Conference or Rio process also famous, it repeats every 5 th year: Rio, Rio +5 : New York, Rio+10: Johanne burg, Rio+15: Rio and Rio+20: Rio.

5 UNFCCC: http://unfccc.int/files/essential_background/convention/background/application/pdf/convention_text_with annexes_english_for_posting.pdf

6 UN General Assembly Resolution 43/53 of 6 December 1988.

7 See more: http://www.ipcc.ch/pdf/ipcc-faq/ipcc_members.pdf

8 See more: http://www.ipcc.ch

9 The decision to prepare a Fifth Assessment Report (AR5) was taken by the members of the IPCC at its 28th Session (09-10 April 2008, Budapest, Hungary). More: http://www.ipcc.ch/report/ar5/index.shtml.

10 See more: http://www.nobelprize.org/nobel_prizes/peace/laureates/2007/ipcc-facts.html 
The Hungarian IPCC members are: Tibor Faragó, Tamás Jászay, Béla Nováky, Zoltán Somogyi and Diana Ürge-Vorsatz.

\section{Dawn of a new international binding agreement}

Human influence on the climate system is clear, and recent anthropogenic emission of greenhouse gases are the highest in history. Recent climate changes have had widespread impacts on human and natural systems.

COP $21^{11}$ and CMP 11 for a universal climate agreement will be held in Paris, these days. The main objective of the COP conferences is to review the Convention's implementation, the first was in Berlin, 1995 and the post-kyoto era was started in COP17 Durban.

Unfortunately the Kyoto Protocol is the only international tool of regulation and originally it expired in 2012. (Kyoto $1^{\text {st }}$ period: 2008-2012., $2^{\text {nd }}$ period after Doha Agreement: 2013-2020) In 2012 after Copenhagen, Cancun and Doha (COP15-18) the biggest question was: when a new international binding agreement will follow the Kyoto Protocol. It did not seem a great problem at first glance, but European Union's speeches in 2012 and onwards highlighted the depth of the problem. The EU pledged to reduce the greenhouse gases by $20 \%$ (till 2020), or even up to $30 \%$ if the Kyoto Protocol is amended by a new international binding agreement. The EU is at the forefront of international negotiations for a new global climate agreement which is due to be finalised by 2015 and implemented from 2020. In forty years we need to have reduced our greenhouse gas emissions by at least $50 \%$ to avoid the worst-case scenarios of climate change. The EU is pressing for an agreement that is ambitious, comprehensive and legally binding in 2015., Paris. Like the Kyoto Protocol, the new agreement has to include the undertakings of industrialised countries to reduce their emissions of certain greenhouse gases which are responsible for global warming.

\section{Comparison of international and regional law}

The international law has one important problem: the binding factor. Every international agreement obligates, however, non-compliant countries face no real repercussions. The normal international agreement is more about diplomacy rather than enforcement. For example many major emitters who are part the UNFCCC, are not part of Kyoto, so it only covers about $18 \%$ of global emissions. The period for signature was from 16 March 1998 to 15 March 1999 at United Nations Headquarters, New York and it had received just 84 signatures. The Protocol entered into force on 16 February 2005., ninety day after the date when not less than 55 Parties to the UNFCCC (incorporating Parties included in Annex I) which accounted in total for at least $55 \%$ of the total carbon dioxide emissions for 1990 (of the Parties included in Annex I), have deposited their instruments of ratification, acceptance, approval or accession.

The conception, international law is derived from ius gentium in ancient Roman law and it means the law for peregrinus ${ }^{12}$. It formed and changed during the times and it had a new name ius inter gentes, this name was the base of the English translation by J. Bentham. In the modern legislation the international law's base the voluntarity of states and it means in the other hand that the states restrict our suvereignty.

11 COP: „Conference of the Parties” means the Conference of the Parties to the Convention. (Kyoto Protocol Article 1.) 12 It was the term used during the early Roman empire, from $30 \mathrm{BC}$ to $212 \mathrm{AD}$, to denote a free provincial subject of the Empire who was not a Roman citizen. 
Every country has our interest and these are different, that is the reason why need the international law the compromise. Other hand, in the international law, the states need the ours claim validation to use self-help. Because of none an international court above the whole country of the world. Manage this problem states gave the opportunity most of the international organization the opportunity to control of the international agreements, but it is generate other problems with composition of executive bodies and the right for veto.

What does regional law mean in the international legislation? If we could differentiate international agreements, the easiest way is the number or states. We know bi- and multilateral agreements ${ }^{13}$ and in the climate change legislation the regional means just EU as an economic integration and European law in front of the UN's nations with EU or EU's states and international law.

The problem is between agreements's signature and ratification. The Vienna Convention on the Law of Treaties (1969.) regulates the international agreements's procedure. As the Article 2. 1. (a)-(b) contain ,treaty” means an international agreement concluded between States in written form and governed by international law, whether embodied in a single instrument or in two or more related instruments and whatever its particular designation. ,ratification” means in each case the international act so named whereby a State establishes on the international plane its consent to be bound by a treaty.

The United States of America signed the Porotocol but never ratified ${ }^{14}$ for various reasons. Unratification by one of the most pollutant countries is a huge problem. However, it bears no real consequences apart from regular disapproval and urging for ratification by other countries. In USA it is business as usual, while the EU or other parties who ratified the Protocol must change their emission. Of course the USA's states made laws and rules about mitigation, for example $\mathrm{NO}_{x}$ budget trading program, but $\mathrm{NO}_{x}$ does not the equal GHGs.

Why does different the EU's climate change law? Because the EU is a supranational integration. It has tools of intervention in case a country fails to achieve targets. The EU is a party as an economical integration in the Protocol and for example, the Commission determines the respective emission levels allocated to the Community and each of its Member States under the Kyoto Protocol in the 2006/944 EC Decision ${ }^{15}$. It has exact and quantified emission limitation and reduction for member countries and the European Commission has the procedure "failure of a Member State" to fulfil obligations if a Member State fails to comply. For example when the Grand Duchy of Luxemburg failed to communicate the information required by 15 March 2007 under Article 3(2) of Decision No 280/2004/EC of the European Parliament and of the Council of 11 February 2004 concerning a mechanism for monitoring Community greenhouse gas emissions and for implementing the Kyoto Protocol, read in conjunction with Articles 8 to 11 of Commission Decision No 2005/166/EC of 10 February 2005 laying down rules implementing Decision No 280/2004/EC, the Curia declared that Grand Duchy of Luxembourg failed to fulfil its obligations under those provisions. The Curia ordered the Grand Duchy of Luxembourg to pay the costs ${ }^{16}$.

13 The different is: bilateral agreement has just two signer, multilateral means more than two.

14 See the Protocol's Annex B, the parties.

15 Comission Decision of 14. December 2006. determining the respective emission levels allocated to the Community and each of its Member States under the Kyoto Protocol pursuant to Council Decision 2002/358/EC.

16 Case C-390/08. Judgment of the Court (Seventh Chamber) of 14 May 2009 - Commission of the European Communities v Grand Duchy of Luxembourg. 


\section{The United Nation Framework Convention on Climate Change (UNFCCC)}

The UNFCCC came into force on 21 March 1994., 195 countries have ratified the Convention, they are called as Parties to the Convention. The UNFCCC was the first international agreement which defined ${ }^{17}$ that the climate change has anthropological causes directly or indirectly. The other well-known definition (Article 3, Principles) is the „common but differentiated responsibilities and respective capabilities." This principle is very popular, appearing in many EU's basic documents on climate change policy ${ }^{18}$. The UNFCCC has some obligations, but, as any other international agreement, the UNFCCC lacks the tools of enforcement. One of the most important objectives is that the Parties of the Convention will stabilize greenhouse gas concentrations ,at a level that would prevent dangerous anthropogenic (human induced) interference with the climate system." The industrialized countries (Annex I countries and belong to the Organization for Economic Cooperation and Development (OECD) are expected to do their utmost to cut emissions on home ground. They also include the European Economic Community (it means today EU) and „economies in transition” from Central and Eastern Europe, like Hungary. Annex I countries were expected to reduce emissions to 1990 levels by the year 2000. These nations agreed to support climate change activities in developing countries by providing financial support for action on climate change and share technology with them. A system of grants and loans has been set up and is managed by the Global Environment Facility. Annex I's countries have to report regularly on their climate change policies and measures under the Convention by submitting an annual report of their greenhouse gas (GHG) emissions. The Framework Convention made a large contribution towards the establishment of key principles of the international fight against climate change. In particular, it defines the principle of ,common but differentiated responsibility”. It also helped to make people all over the world more aware of the problems linked to climate change. It only encourages the commitment of the industrialized countries to stabilize greenhouse gas emissions under the Convention. The binding emission reduction targets for 37 industrialized countries and the European community is set in an other agreement, the Kyoto Protocol.

\section{The Kyoto Protocol}

Emissions scenarios ${ }^{19}$ leading to $\mathrm{CO}_{2}$-equivalent $\left(\mathrm{CO}_{2 \mathrm{e}}\right)$ concentrations in 2100 of about $450 \mathrm{ppm}$ or lower are likely to maintain warming below $2{ }^{\circ} \mathrm{C}$ over the 21 st century relative to pre-industrial levels. These scenarios are characterized by 40 to $70 \%$ global anthropogenic GHG emissions reductions by 2050 compared to 2010, and emissions levels near zero or below in 2100. Mitigation scenarios reaching concentration levels of about $500 \mathrm{ppm} \mathrm{CO}_{2 \mathrm{e}}$ by 2100 are more likely than not to limit temperature change to less than $2^{\circ} \mathrm{C}$, unless they temporarily overshoot concentration levels of roughly $530 \mathrm{ppmCO}_{2 \mathrm{e}}$. Summary for Policymakers SPM before 2100 , in which case they are about as likely as not to achieve that goal. In these $500 \mathrm{ppm}$ $\mathrm{CO}_{2 \mathrm{e}}$ scenarios, global 2050 emissions levels are 25 to $55 \%$ lower than in 2010.

17 See UNFCCC Article 1. The definitions: 2. „climate change”: means a change of climate which is attributed directly or indirectly to human activity... or Article 2. Objective.

18 Example: Communication from the Commission to the Council, the European Parliament, the European Economic and Social Committee and the Committe of the Regions: Limiting Global Climate Change to 2 degrees Celsius The way ahead for 2020 and beyond; B russels, 10.1.2007, $\operatorname{COM}(2007) 2$ final.

19 Emisson scenarios: IPCC's scenarios exemple in Fifth Assessment Report of the Intergovernmental Panel on Climate change. 
Scenarios with higher emissions in 2050 are characterized by a greater ${ }^{20}$. In the EU's commitment, to achieve this the world needs to stop the increase in greenhouse gas emissions by 2020 and reduce them by $60 \%$ by 2050 compared with 2010 .

The Kyoto Protocol is one of the chief instruments for tackling climate change. The Kyoto Protocol is an international agreement linked to the UNFCCC, where the Parties are committed by set internationally binding emission reduction targets. It was adopted in Kyoto, on 11 . December in 1997., in the 3th Conference of the Parties (COP 3. $)^{21}$, but it just came into force only on 16 February 2005.

In 1997. the Kyoto Agreement was established by 38 states and one regional economic integration, which has the name, EU today. To come into force, the protocol had a rule for itself, Article 25th, ,on the ninetieth day after the date on which not less than 55 Parties to the Convention, incorporating Parties included in Annex I which accounted in total for at least 55 per cent of the total carbon dioxide emissions for 1990 of the Parties included in Annex I, have deposited their instruments of ratification, acceptance, approval or accession." The problem with coming to force was some countries' reluctance to ratify it like United States of America or Australia. At the end, Australia ratified the Protocol in 3. December 2007.

First of all, the most important rule in the Protocol, was the reduction obligation. Annex $\mathrm{B}$ to the Protocol contains the quantified commitments given by the Annex I's parties ${ }^{22}$ when they shall ensure that their aggregate anthropogenic carbon dioxide equivalent emissions of the greenhouse gases do not exceed their assigned amounts and reduce their overall emissions of GHGs by at least 5 per cent. The EU's reduction target ( 8 per cent, arbitrarily set by any given country) was broken down into legally binding national targets, so the EU's reduction target was legally more forcing than the basic Protocol for any other Parties.

The commitment period was between 2008 and 2012, and the baseline year was 1990 for most of the parties. The assigned amounts are calculated pursuant to their quantified emission, limitation and reduction commitments inscribed in Annex B. The GHGs are listed in Annex A, the list consists of four gases and two groups of gases: carbon dioxide $\left(\mathrm{CO}_{2}\right)$; methane $\left(\mathrm{CH}_{4}\right)$; nitrous oxide $\left(\mathrm{N}_{2} \mathrm{O}\right)$; sulphur hexafluoride and $\left(\mathrm{SF}_{6}\right)$ hydrofluorocarbons (HFCs); perfluorocarbons (PFCs) respectively. Each GHG is characterized by its total warming impact relative to $\mathrm{CO}_{2}$ over a set period - usually a hundred years. Equivalent $\mathrm{CO}_{2}$ is a standard unit for measuring carbon footprints, its calculation is based on global warming potential (GWP) and it gives the concentration of $\mathrm{CO}_{2}$ that would cause the same level of radiative forcing as a given type and concentration of GHG. The six greenhouse gases tackled by the Kyoto Protocol are not controlled by the Montreal Protocol.

To achieve this goal, the Protocol has some interesting rules. If you compare the UNFCCC and the Protocol you can find that the goals or targets are more or less the same, but the methods to achieve them are very different. The Protocol is potentially more efficient by setting the goals as obligations and/or opportunity. Each Annex I party has the responsibility, ,in achieving its quantified emission limitation and reduction commitments under Article 3, in order to promote sustainable development", said Article 2.

20 IPCC, 2014: Climate Change 2014: Synthesis Report. Contribution of Working Groups I, II and III to the Fifth Assessment Report of the Intergovernmental Panel on Climate Change [Core Writing Team, R.K. Pachauri and L.A. Meyer (eds.)]. IPCC, Geneva, Switzerland, $151 \mathrm{pp}$.

21 COP1.: 1995. Berlin, COP2.: 1996. Genf.

22 The Protocol use „Party” unless the context otherwise indicates, a Party to this Protocol, and „Party included in Annex I” means a Party included in Annex I to the Convention, as may be amended, or a Party which has made a notification under Article 4, paragraph 2(g), of the Convention 
Any Annex I Parties implement and/or further elaborate policies and measures in accordance with its national circumstances. They have to implement the energy efficiency; promotion of sustainable forest management practices, afforestation and reforestation, sustainable forms of agriculture in light of climate change considerations. This complex sector is also known as LULUCF ${ }^{23}$. Activities in the LULUCF sector can provide a relatively cost-effective way of offsetting emissions, either by increasing the removals of greenhouse gases from the atmosphere, or by reducing emissions. But, unfortunately, it is very difficult to estimate greenhouse gas removals and emissions resulting from activities of LULUCF and greenhouse gases may be unintentionally released into the atmosphere if a sink is damaged or destroyed by a forest fire or disease. Under Article 3.3 of the Kyoto Protocol, Parties decided that greenhouse gas removals and emissions through certain activities are accounted for in meeting the Kyoto Protocol's emission targets. Emissions from deforestation activities will be subtracted from the amount of emissions that an Annex I Party may emit over its commitment period. Under Article 3.4 of the Kyoto Protocol, Parties could elect additional human-induced activities related to LULUCF, specifically forest management, cropland management, grazing land management and revegetation, to be included in its accounting for the first commitment period. The LULUCF rules are more wide than the Kyoto Protol's, so it has an own agreement, the Marrakesh Accords.

Article 2 outlines the obligation for research on promotion, development and increased use of, new and renewable forms of energy, of carbon dioxide sequestration technologies and of advanced and innovative environmentally sound technologies. It also encourages reforms in relevant sectors aimed at promoting policies and measures which limit or reduce emissions of GHG. Measures are given to limit and/or reduce emissions of GHG in the transport sector. The issue of limitation and/or reduction of methane emissions through recovery and use in waste management, as well as in the production, transport and distribution of energy is also dealt with.

The most interesting task in the Article 2 is the fifth: ,progressive reduction or phasing out of market imperfections, fiscal incentives, tax and duty exemptions and subsidies in all greenhouse gas emitting sectors that run counter to the objective of the Convention and application of market instruments." This rule is older than the Protocol, by Organisation for Economic Co-operation and Development (OECD). It implies to make the polluter financially responsible for the environmental damage caused. Unfortunately the original rule is very strict, so the modern environmental law and policy uses it with large exceptions, because if you use it in the original form, it forecloses every support in the environment when you support the polluter to reduce the pollution.

The Protocol has three tools to achieve the goals of Article 2. These are: clean development mechanism - CDM, join implementation - JI and emission trade. A CDM project must provide emission reductions that are additional to what would otherwise have occurred. The projects must qualify through a rigorous and public registration and issuance process. Approval is given by the Designated National Authorities. The mechanism stimulates sustainable development and emission reductions, while giving industrialized countries some flexibility in how they meet their emission reduction limitation targets. Public funding for CDM project activities must not result in the diversion of official development assistance. The mechanism is overseen by the CDM Executive Board, answerable ultimately to the countries that have ratified the Kyoto Protocol.

23 LULUCF: Land Use, Land-Use Change and Forestry. 
Operational since the beginning of 2006, the mechanism has already registered more than 1,650 projects and is anticipated to produce certified emission reduction, CERs amounting to more than 2.9 billion tonnes of $\mathrm{CO} 2$ equivalent in the first commitment period of the Kyoto Protocol, 2008-2012.

The JI allows a country with an emission reduction or limitation commitment under the Kyoto Protocol (Annex B Party) to earn emission reduction units (ERUs) from an emissionreduction or emission removal project in another Annex B Party, each equivalent to one ton of $\mathrm{CO}_{2}$, which can be counted towards meeting its Kyoto target. Projects starting as from the year 2000 may be eligible as JI projects if they meet the relevant requirements, but ERUs may only be issued for a crediting period starting after the beginning of 2008. A certified emission reduction or "CER" is a unit issued pursuant to Article 12 and requirements thereunder, as well as the relevant provisions in the annex to decision 3/CMP.1, and is equal to one metric tonne of carbon dioxide equivalent, calculate using global warming potentials defined by decision 2/CP.3 or as subsequently revised in accordance with Article 5. An assigned amount unit or "AAU" is a unit whitch is equal to one metric tonne of carbon dioxide equivalent, calculated using global warming potentials as CER. The Joint Implementation Supervisory Committee (JISC) adopted at its eighteenth meeting in October 2009, a procedure for joint implementation programmes of activities (JI PoA) under JI Track 2. JI PoAs can be submitted under this procedure as of 1 December, 2009.

The most well-known is the third one, the emission trade. This resort from Article 6 is the base for some country and one economical integration, the EU's GHG markets, like ETS in EU. The ETS and others could be the most effective solution in the war against climate change. Of course, these systems are not perfect, they have many problems, like "the law for pollution" or "hot air syndrome". However, nowadays the ETS has the most effective tool in EU's climate change policy, although in eleven years we need to have achieved at least a $25 \%$ reduction in emissions for target $2^{\circ} \mathrm{C}$.

\section{SWOT analysis in two forms of legislation}

The best method to analyse international and regional legislation in the field of climate change is to compare them to each other. First of all compromise which needs numerous participants in the international level. But compromise is weakness at the same time proved by the events around the Kyoto Protocol and in the Post Kyoto era. The procedure which was started in 2009, Copenhagen had and have a lot of question about the future of Kyoto's target and a new international agreement. You can see the many participants as an opportunity to manage the environment problems, especially climate change which does not respect the states' borders. Climate change is a global problem so it needs a global solution not just a regional. The strengths could be followed with the preliminary works which predates approval. Many countries work together. These countries could implement the international rules easier. On the other hand the international agreements have a model that the countries or the EU could follow without participating in the preliminary works, helping to evaluate the new models like emission trading in Kyoto Protocol. What are the strengths the regional legislation in front of the international legislation? The supranationality and the possibility of enforcement as you can read above. The regional legislation could be more effective and strict. The European Union has many target for 2030 and one of them is cut $40 \%$, after till $204060 \%$ the GHG emissions 
compared to 1990 levels. Latest national projections show the EU is heading for a $24 \%$ reduction by 2020 with current measures in place. Emissions from houses and office buildings can be almost completely cut - by around $90 \%$ in 2050 in the EU. For these targets the EU adopted the climate and energy package beyond the Kyoto Protocol and as an important step in these efforts, in 2014 the European Council agreed on the 2030 policy framework for climate and energy. The opportunities of the analysis mean highest targets both at international and regional levels. In regional level the wider sector under the regulation means other opportunity.

On the other hand too high targets are also identified as threat. If the target is too high many countries wouldn't ratify the new blinding international agreements because of the own interest. They can choose the national legislation not just the international, so the balance between enough and executable is very important. The problem is same in the regional level too, for example Hungary in calculated $10 \%$ rise GHG emission as a national target compared to 2005 for $2020^{24}$. Other way the EU and regional legislation couldn't change the world alone, in spite of the really high targets. In 2014 the world whole emission was $35890 \mathrm{MtCO}_{2}^{25}$, China had 9680, USA 5561, India 2597, Russian Federation 1595 and Japan $1231 \mathrm{MtCO}_{2}$. Without the new international binding international agreement this problem couldn't be handled.

Must mention the ETS as the world only emission trade system under the Kyoto Protocol. The international legislation established the opportunity but the regional legislation was that which executed. The ETS could be indentified as an other opportunity. The history of ETS is a good example for the stricter rules and its effectivity. Every phase of ETS was stricter and now the third period has an absolute new system with auctioning without free allocation. In 2013 more than $40 \%$ of allowances will be auctioned, and this share will rise progressively each year. The following, fourth phase will have stricter rules again, like the overall number of emission allowances, which will decline at an annual rate of $2.2 \%$ from 2021 onwards, compared to currently $1.74 \%^{26}$. The proposal translates the $43 \%$ greenhouse gas reduction target in 2030 in the ETS into a cap declining by $2.2 \%$ annually from 2021 onwards, corresponding to an additional reduction of around 556 million tonnes of carbon dioxide in the period 2021-2030. The preliminary findings of a study evaluating the existing ETS Directive in terms of relevance, effectiveness, efficiency, EU-added value and coherence with other Union policies indicate that overall the EU ETS as a policy tool combining environmental regulation with a market instrument is working in practice and delivering on its targets. Meeting the EU's climate targets is highly relevant, as it represents a cost-effective way for emission reductions. Emissions in the covered sectors have decreased steadily, and even though not all emission reductions can be attributed to the EU ETS alone, there is evidence that the system does contribute effectively to emission reductions. The EU ETS facilitates the internalisation of $\mathrm{CO}_{2}$ costs. It has a significant share when investment decisions are taken.

Overrating is another threat in connection with ETS, the emission trade is one but not the only tool in the tools of climate change legislation. As IPPC declared all the instruments in environment legislation have to be used in combination. The Kyoto Protocol didn't mention taxes or standards, but the regional legislation could use them. So this is an other opportunity or strength in regional legislation, because the EU could accept laws in climate change without international agreement's mandate.

24 EUROPE 2020 TARGETS: climate change and energy ANNEX: Additional statistical indicators.

25 See more: Global Carbon Atlas.

26 See more: $\operatorname{COM}(2015) 337$ final; Brussel, 15. 7. 2015 


\section{THE BUILT ENVIRONMENT AND CLIMATE CHANGE}

The built environment and the climate change have a dual connection. The building sector contributes up to $30 \%$ of global annual greenhouse gas emissions and consumes up to $40 \%$ of all energy ${ }^{27}$. And the built environment is the environment where the world's population can adapt to climate change.

Total annual anthropogenic GHG emissions have increased by about $10 \mathrm{GtCO}_{2}$-eq between 2000 and 2010. This increase directly came from the energy (47\%), industry (30\%), transport (11\%) and building (3\%) sectors. ${ }^{28}$ The IPCC's Fourth Assessment Report shows that the potential for greenhouse gas reductions from buildings is common to both developed and developing countries, as well as countries with economies in transition. ${ }^{29}$ Buildings are responsible for more than 40 percent of global energy use and one third of global greenhouse gas emissions, both in developed and developing countries. Buildings account for $40 \%$ of total energy consumption in the European Union ${ }^{30}$. There is an extensive array of technologies that can be used to abate GHG emissions in new and existing buildings.

\section{International connection}

The UN's UNEP prognostized if given this massive grow thin new construction in economies in transition, and the inefficiencies of existing building stock worldwide, so, if nothing is done, the greenhouse gas emissions from buildings will more than double in the next 20 years. Therefore, if targets for greenhouse gas emissions reduction are to be met, it is clear that decision-makers must tackle emissions from the building sector. Mitigation of greenhouse gas emissions from buildings must be a cornerstone of every national climate change strategy.

IPPC's Climate Change 2007: Working Group III: Mitigation of Climate Change Chapter 6 deals with residential and commercial buildings. Many building components, like airconditioning, refrigeration systems, foam products used for insulation and other purposes and fire protection systems - may emit greenhouse gases with relatively high global-warming potentials. At many airconditioning and refrigeration appliances, the $\mathrm{CO}_{2}$ emitted during the generation of electricity to power the equipment will typically vastly outweigh the equivalent emissions of the HFC refrigerant. They advise the legislators to utilise more technology standards in legislation with combination emission taxes. In the end they cited voluntarity and defined the EU's ETS as the world's largest tradable permits program. In summary the document advises on all the possible tools and their combination in environmental legislation.

27 United NationsEnvironmentProgramme (UNEP): Buildings and Climate Change Summary for Decision-Makers, 2009 UNEP DTIE, Paris, France.

28 IPCC, 2014: ClimateChange 2014: SynthesisReport. Contribution of Working Groups I, II and III to the Fifth Assessment Report of theIntergovernmental Panel on Climate Change [CoreWriting Team, R.K. Pachauri and L.A. Meyer (eds.)]. IPCC, Geneva, Switzerland, $151 \mathrm{pp}$.

29 United Nations Environment Programme (UNEP): Buildings and Climate Change Summary for Decision-Makers, 2009 UNEP DTIE, Paris, France.

30 Directive 2010/31/EU of the European Parliament and of the Council, on the energy performance of buildings; 19 . May 2010. 


\section{Regional connection}

The European Union has even created an "Intelligent Energy Europe" agency to manage energy efficiency projects - including ones targeting buildings, as well as to help establish local and regional energy efficiency agencies. The Intelligent Energy - Europe (IEE) is now closed, although a number of projects funded under the programme are continuing under Horizon 2020. Buildings have an impact on long-term energy consumption and major renovations of existing buildings, regardless of their size, provide an opportunity to take cost-effective measures to enhance energy performance. The EU's 2020 energy strategy has three targets in climate change and energy sustainability. First: reduction of greenhouse gas emissions by $20 \%$ (or even $30 \%$, if the conditions are right, as mentioned earlier) from levels in 1990 (Kyoto's base date). Second: increase proportion of renewables to $20 \%$ of and the third is to aim $20 \%$ increase in energy efficiency ${ }^{31}$. The plan proposes the use of regulation, building performance standards and market-based instruments such as taxation, subsidies and procurement to reduce energy and resource use and use structural funds to invest in energy efficiency in public buildings and in more efficient recycling.

In the 2030 framework for climate and energy policies (9th of May, 2010) the EU accepted a directive on the energy performance of buildings ${ }^{32}$. As you can read in the Directive: „This Directive promotes the improvement of the energy performance of buildings within the Union, taking into account outdoor climatic and local conditions, as well as indoor climate requirements and cost-effectiveness." The directive has 7 requirements as in: common general framework in methodology for calculating, minimum requirements of the energy performance, national plans in nearly zero-energy buildings, energy certification, regular inspection of heating and air-conditioning systems in buildings and inspection reports. The member states are obliged to set minimum energy performance requirements, related requirements are in the Article 4 and 9. The member states and the EU have to have financial incentives to catalyse the energy performance of buildings and the transition to nearly zero-energy buildings. Article 1116 contains the Energy performance certificates, and the minimum and optimal requirements with certificates and the whole procedure. Expectations of independent experts and the control system are to be fulfilled. The independent experts have to be qualified and/or accredited, the independent control system could be operated by authorities, but not necessarily. The 27th Article has a collateral directive declaring the obligation of penalties as the member states' duty.

Unfortunately as the international level, the regional levels hasn't the binding factor. The UNEP documents can use as a recommendation, the EU's framework exist tasks and objects, but the concrete execution needs other laws, like regulations or directive.

$31 \operatorname{COM}(2010) 2020$ final, Communicaton from the Comission: EUROPE 2020 A strategy for smart, sustainable and inclusive growth; Brussels, 3.3.2010.

32 Directive 2010/31/EU of the European Parliament and of the Council, on the energy performance of buildings; 19. May 2010. 


\section{CONCLUSION}

The current global average temperature is $0.85^{\circ} \mathrm{C}$ higher than it was in the late 19th century. Each of the past three decades has been warmer than any preceding decade since records began in 1850. The world's leading climate scientists, as IPCC think human activities are almost certainly the main cause of the warming observed since the middle of the $20^{\text {th }}$ century. An increase of $2^{\circ} \mathrm{C}$ compared to the temperature in pre-industrial times is seen by scientists as the threshold beyond which there is a much higher risk of dangerous and possibly catastrophic changes in the global environment. In 2012, the EU was responsible for some $10 \%$ of world greenhouse emissions. Pending final assessment of compliance by the Kyoto Protocol, the EU has achieved an overall cut of $11.8 \%$ domestically, without counting the additional reductions coming from carbon sinks (LULUCF) and international credits. This figure can be misleading due to the financial crisis of 2008 and the resulting underperformance of the industrial sector. The EU has set itself targets to reduce its greenhouse gas emissions progressively up to 2050, as 2020 climate and energy package, 2030 climate and energy framework, 2050 low carbon roadmap and finally EU has an European Climate Change Programme. The world is about to agree on it this year, hopefully in a new international binding agreement. The new agreement must have higher targets than Kyoto's 5\%, like EU's legislation and the base year is an other question, because of the countries that were undergoing the process of transition to a market economy in 1997. Finally, without the three large emitter parties like India, China, and the United States neither the new agreement nor the target of $2{ }^{\circ} \mathrm{C}$ would be possible. 


\section{REFERENCES}

[1] M. D. H. JONES, A. HENDERSON-SELLERS: History of the Greenhouse Effect, Prog. Phys. Geog. 14, no. 1; 1990.

[2] JAMES RODGER FLEMING: Historical Perspectives on Climate Change; Oxford University Press, 1998. New York.

[3] SVANTE ARRHENIUS: On the Influence of Carbonic Acid in the Air upon the Temperature of the Ground; Philosophical Magazine and Journal of Science, Series 5, Volume 41, April 1896.

[4] MEGHAN MCGUINESS, A. DENNY ELLERMANN: The effects of interactions between federal and state climate policies, MIT Center for Energy and Environmental Policy Research, 2008.

[5] OLIVER TICKELL: Kyoto2, How to manage the global Greenhouse; Zed Books Ltd. 2008. ISBN: 978-1-84813-024-1.

[6] SONJA BOEHMER-CHRISTIANSEN, AYNSLEY KELLOW: International Environmental Policy Interests and the Failure of the Kyoto Process; Edward Elgar Publishing Limited 2002.; ISBN 184064818 X

[7] BRUHÁCS JÁNOS: Nemzetközi jog I. Általános rész. Dialog Campus Institutiones Juris, Budapest-Pécs; 2004. ISBN: 9638575670.

[8] Implementing the climate regime; International Compliance. Edited by Olav Schram Stokke, Jon Hovi and Geir Ulfstein; Earthscan UK and USA in 2005; ISBN: 1-84407-161-8.

[9] The Intergovernmental Panel on Climate Change (IPCC): Climate Change 2013. The Physical Science Basis s. Contribution of Working Group I to the Fifth Assessment Report of the Intergovernmental Panel on Climate Change [Stocker, T.F., D. Qin, G.-K. Plattner, M. Tignor, S.K. Allen, J. Boschung, A. Nauels, Y. Xia, V. Bex and P.M. Midgley (eds.)]. Cambridge University Press, Cambridge, United Kingdom and New York, NY, USA.

[10] UNFCCC: http://unfccc.int/files/essential_background/convention/background/application/pdf/convention text_with_annexes_english_for_posting.pdf.

[11] Kyoto Protocol: http://unfecc.int/kyoto_protocol

[12] 2006/944/EC Comission Decision of 14 . December 2006. determining the respective emission levels allocated to the Community and each of its Member States under the Kyoto Protocol pursuant to Council Decision 2002/358/EC. 16.12.2006. Official Journal of the European Union L 358/87.

[13] Communication from the Commission to the Council, the European Parliament, the European Economic and Social Committee and the Committe of the Regions: Limiting Global Climate Change to 2 degrees Celsius The way ahead for 2020 and beyond; B russels, 10.1.2007, $\operatorname{COM}(2007) 2$ final.

[14] IPCC, 2014: Climate Change 2014: Synthesis Report. Contribution of Working Groups I, II and III to the Fifth Assessment Report of the Intergovernmental Panel on Climate Change [Core Writing Team, R.K. Pachauri and L.A. Meyer (eds.)]. IPCC, Geneva, Switzerland.

[15] IPCC 2014, 2013 Revised Supplementary Methods and Good Practice Guidance Arising from the Kyoto Protocol, Hiraishi, T., Krug, T., Tanabe, K., Srivastava, N., Baasansuren, J., Fukuda, M. and Troxler, T.G. (eds) Published: IPCC, Switzerland.

[16] Global Carbon Atlas: http://www.globalcarbonatlas.org

[17] United NationsEnvironmentProgramme (UNEP): Buildings and Climate Change Summary for Decision-Makers, 2009. UNEP DTIE, Paris, France.

[18] Directive 2010/31/EU of the European Parliament and of the Council, on the energy performance of buildings; 19. May 2010.

[19] $\operatorname{COM(2010)} 2020$ final, Communicaton from the Comission: EUROPE 2020 A strategy for smart, sustainable and inclusive growth; Brussels, 3.3.2010

[20] Directive 2010/31/EU of the European Parliament and of the Council, on the energy performance of buildings; 19. May 2010.

[21] Comission Staff Working Paper Analysis of options beyond 20\% GHG emission reductions: Member State results Brussels, 1.2.2012 SWD (2012) 5 final.

[22] Case C-390/08. Judgment of the Court (Seventh Chamber) of 14 May 2009 - Commission of the European Communities v Grand Duchy of Luxembourg. 